\title{
Substantial Evidence to Localize the Developmental Origin of Primordial Germ Cells in the Chicken
}

\author{
Hiroshi KAGAMI, Junko IWATA, Asako NAKATA, Takahiro TAGAMI", \\ Yuko MATSUBARA ${ }^{1}$, Takashi HARUMI ${ }^{1}$, Chikashi TACHI, Hisato OKABAYASHI, \\ Naomi KASHIWAZAKI, Masao SHINO and Misturu NAITO ${ }^{1}$ \\ School of Veterinary Medicine, Azabu University, Sagamihara-shi 229-8501, Japan \\ ${ }^{1}$ National Institute of Animal Industry, Tsukuba Norin Kenkyu Danchi, \\ Ibaraki-ken 305-0901, Japan
}

(Received July 19, 1999 ; Accepted August 19, 1999)

\begin{abstract}
The developmental origin of the primordial germ cells (pgcs) in avian embryos was substantially localized at the center of area pellucida. A cell cluster consisting of about 700 cells was isolated from : 1) the center of area pellucida, 2) the outer of area pellucida and 3) the area opaca of the stage $\mathrm{X}^{5)}$ blastoderm. The isolated cell cluster was dissociated and about 500 cells were microinjected into the recipient stage $\mathrm{X}$ blastoderm, from which a cell cluster of about 700 cells at the center of area pellucida were removed. These chimeric embryos were cultured until stage $15^{8}$. When the donor cells from area 2) or 3) were microinjected into the recipient, the mean number of pges per $1 \mu \mathrm{l}$ of blood decreased significantly to 7 or $11(P<0.05)$, respectively, as compared to intact embryos with 62. When the cells were replenished with the donor cells from area 1), no reduction in the pgcs number was observed. The replenishment of the recipients' cells by the cells from area 2) or 3) could not restore the original number of pgc. Therefore, it was concluded that the pgcs originated in the central part of the area pellucida and that there were few pgcs at the outer of area pellucida or area opaca.
\end{abstract}

Animal Science Journal 71 (1) : 38-41, 2000

Key words : Blastoderm, Origin of pgc, Avian chimera, Embryo engineering

Determination of the origin of primordial germ cells (pgcs) and it's use as the vector of foreign genes can lead to the development of transgenic poultry ${ }^{4,9,11,15-17,21)}$. Extensive efforts have been made to determine the origin of the avian pges. The pgcs were localized in the epiblast of stage $X^{5)}$ blastoderm by immuno-staining using epitopes such as EMA-1, SSEA-1 and QH-1 1, 13,18,25). Despite extensive efforts in these studies, the localization of pgcs within the blastoderm has not been determined precisely. There is little evidence to support that putative pges which are detected by the immuno-staining could be differentiated into the gametes, i.e., spermatozoa in males and ova in females ${ }^{3,6)}$.
To determine the origin of pgcs more directly, deletion and chimeric studies were performed ${ }^{10,22)}$. When a cell cluster, of about 700 cells, was removed from the center of area pellucida at the stage $X$ blastoderm and cultured ex vivo, the mean number of pgcs in the circulating blood significantly decreased in the embryo at stage $15^{8}$, as compared to intact embryos. The decrease of pgc numbers in the embryos at stage 15 recovered in chimeras produced by an injection of the donor blastoderm into a recipient blastoderm from which cells at the center of area pellucida were removed. It was concluded that the pgcs originated at the central part of area pellucida of stage $\mathrm{X}^{5}$ blastoderms. However, the region of

Corresponding : Hiroshi KAGAMI (fax : +81 (0) 42-753-3395, e-mail : kagami@azabu-u.ac.jp)

Anim. Sci. J. 71 (1) : $38-41,2000$ 


\section{Origin of Avian pge}

blastoderm from which donor cells were obtained was not clearly defined in the last studies.

In the present study, the donor cells from a clearly defined region of the blastoderm : 1) the center of area pellucida, 2) the outer of area pellucida and 3 ) the area opaca, were microinjected into the recipient blastoderm from which the cells at the center of area pellucida was removed. The number of pges in the circulating blood in the stage $15^{8)}$ embryo was counted and compared to intact embryos. This approach would substantially clarify the developmental origin of the pges in the blastoderm.

\section{Materials and Methods}

\section{Chimeric embryo}

The donor and recipient embryos were from White Leghorn chickens. The donor embryos, stage $\mathrm{X}^{5 \text { ? }}$ blastoderm in freshly laid and unincubated eggs, were separated from the egg yolk and washed with phosphate-buffered saline (PBS). A cell cluster, consisting of about 700 cells, was isolated from a clearly defined region of the blastoderm : 1) the center of area pellucida, 2) the outer of area pellucida and 3 ) the area opaca. The cluster was dissociated with trypsin and dispersed in Dulbecco's Modified Eagle's Medium (DMEM) containing 10\% chicken serum ${ }^{2}$. The recipients were fertilized eggs containing a stage $\mathrm{X}$ blastoderm. According to the method of Kagami et $a l^{10)}$, a cell cluster containing approximately 700 cells was aspirated from the center of the area pellucida. Initially prepared donor cells of about 500 were microinjected into the treated recipients. The manipulated embryos were ex vivo cultured ${ }^{14,19)}$ until stage $15^{8}$.

\section{pgc number in circulating blood}

Blood samples of about $5 \mu l$ were collected from the stage $15^{8)}$ embryos. Each blood sample was diluted to $200 \mu l$ with PBS and centrifuged for 5 minutes at $1,000 \mathrm{~g}$ to wash the cells. The supernatant was removed and the cell pellets were resuspended in $200 \mu \mathrm{l}$ of PBS. The cells were fixed with $3.7 \%$ formaldehyde in PBS. The fixed samples of $7 \mu l$ were placed on a glass cell culture slide and covered with $0.05 \%$ celloidin dissolved in ethanol. The fixed cells were then stained with periodic acid-Shiff (PAS) ${ }^{12)}$ to iden- tify the pgcs and the number of pges (PAS-positive cells) were counted under a light microscope ${ }^{24)}$. The $t$-test was used to identify statistically significant differences in the mean number of pgc between the derivation of donor.

\section{Results}

When the blood samples from stage $15^{8}$ embryos were stained by the PAS staining, only the pgcs were stained dark red, whilst the other blood cells were not stained at all. In the intact stage 15 embryos (Table $1)$, the number of pges per $1 \mu l$ of embryonic blood was 62 . When the 500 donor cells, derived from the area 2) or 3), were microinjected into the treated recipient, the mean number of circulating pges per $1 \mu l$ of blood significantly decreased to 7 or $11(\mathbf{P}<0.05)$ in the embryo at stage 15 as compared to the intact embryos with 62 . When the cells were replenished with the 500 donor cells derived from area 1), the number of pges per $1 \mu \mathrm{l}$ of embryonic blood was 60 which was not significantly different from the intact embryos. The replenishment of recipient cells by use of the donor cells from area 1) could restore the number of pgc at the stage 15 , but could not restore the number with donors from area 2 ) or 3 ).

\section{Discussion}

Recent studies on the production of germline chimeras indicate that the blastoderm, as well as isolated

Table 1. Number of PGCs in chimeric embryos at stage 15 (Hamburger and Hamilton, 1951)

\begin{tabular}{ccc}
\hline $\begin{array}{c}\text { Derivation of } \\
\text { donor }\end{array}$ & $\begin{array}{c}\text { No. of embryos } \\
\text { counted }\end{array}$ & $\begin{array}{c}\text { No of PGCs in } \\
\text { the embryos }{ }^{1)}\end{array}$ \\
\hline Control & 15 & $62.3 \pm 9.5^{\mathrm{a}}$ \\
CAP $^{2)}$ & 25 & $59.7 \pm 7.5^{\mathrm{a}}$ \\
OAP $^{3)}$ & 23 & $7.4 \pm 6.2^{\mathrm{b}}$ \\
$\mathrm{AO}^{4)}$ & 27 & $11.1 \pm 7.1^{\mathrm{b}}$ \\
\hline
\end{tabular}

1) The number of PGCs \pm standard deviation per $\mu l$ of embryonic blood at stage 15 .

2) CAP, Center of Area Pellucida ;

${ }^{3 /}$ OAP, Outer of Area Pellucida ;

4) AO, Area Opaca.

${ }^{\mathrm{a}, \mathrm{b}}$ Values without common superscripts are significantly different $(\mathbf{P}<0.05)$. 
pges, could be used to transfer foreign DNA into the avian germline $e^{1,15,20,23,26)}$. Determination of the origin of pges in the developing embryo can lead to the development of transgenic poultry ${ }^{17,22)}$. By means of immuno-staining using epitopes such as EMA-1, SSEA-1 and QH-1, extensive efforts have been made in determining the origin of the avian $\mathrm{pgcs}^{7,13,18,25)}$. The pgcs were localized in the epiblast of stage $X$ blastoderms. However, the localization of pgcs within the blastoderm has not been determined precisely, with little evidence to support that putative pgcs which are detected by immuno-staining could be differentiated into the gametes, i.e., spermatozoa in males and ova in females ${ }^{3,6)}$.

Kagami et al. ${ }^{10)}$ first determined the origin of avian pges directly, both in vivo and in vitro, with deletion and chimeric studies. It was found that the pges originated at the central part of the area pellucida of stage $\mathrm{X}$ blastoderms. However, the region of blastoderm from which donor cells were obtained was not clearly defined in the last study. In the present study, the donor cells from a clearly defined region of the blastoderm : 1) the center of area pellucida, 2) the outer of area pellucida and 3) the area opaca, was microinjected into the recipient blastoderms from which cells at the center of the area pellucida were removed. When the donor cells from area 2) or 3) were microinjected into the treated recipient, the mean number of circulating pgcs per $1 \mu \mathrm{l}$ of blood significantly decreased in the embryo at stage 15 , as compared to intact embryos. When the cells were replenished with donor cells derived from area 1), no reduction in the pges number was observed. The replenishment of the recipient cells by use of the cells from area 2) or 3 ) could not restore the number of pgc.

These results clarify conclusively that the pgcs originate at the central part of the area pellucida and that there are few pgcs at the outer of area pellucida or of area opaca.

\section{Acknowledgements}

The authors would like to express their sincere thanks to Mr. A. Nisbet for proof reading of the manuscript. The present study was supported by a

Anim. Sci. J. 71 (1) : $38^{-41,2000}$
Grant-in-Aid for Encouragement of Young Scientists, The Ministry of Education, Science, Sports and Culture of the Japanese Government.

\section{References}

1) Brazolot CL, Petitte JN, Etches RJ, Gibbins AM. Efficient transfection of chicken cells by lipofection and introduction of transfected blastodermal cells into the embryo. Molecular Reproduction and Development, $30:$ 303-312. 1991.

2) Carsience RS, Clark ME, Gibbins AM, Etches RJ. Germline chimeric chickens from dispersed donor blastodermal cells and compromised recipient embryos. Development, $117: 669-675.1993$.

3) Etches RJ, Clark ME, Toner A, Liu G, Gibbins AM. Contributions to somatic and germline lineages of chicken blastodermal cells maintained in culture. $\mathrm{Mo}$ lecular Reproduction and Development, 45 : 291-298. 1996.

4) Etches RJ, Kagami H. Genotypic and phenotypic sex reversal. In : Perspectives in Avian Endocrinology. (Etches RJ ed.) 57-67. Journal of Endocrinology Ltd. Bristol UK. 1997.

5) Eyal-Giladi H, Kochav $S$. From cleavage to primitive streak formation: a complementary normal table and a new look at the first stage of the development of the chicken I. General Morphology. Developmental Biology, 49 : 321-337. 1976.

6) Eyal-Giladi H. Early determination and morphogenetic processes in birds. In : Manipulation of the Avian Genome. (Etches RJ, Gibbins AM eds.) 29-37. CRC Press. Boca Raton. 1993.

7) Ginsburg M, Eyal-Giladi H. Primordial germ cell development in cultures of dispersed central disks of stage $\mathrm{X}$ chicken blastoderms. Gamete Research, 23 : 421-428. 1989.

8) Hamburger V, Hamilton HL. A series of normal stages in the development of the chick. Journal of Morphology, 88: 49-92. 1951.

9) Kagami H, Clark ME, Gibbins AM, Etches RJ. Sexual differentiation of chimeric chickens containing $\mathrm{ZZ}$ and $\mathrm{ZW}$ cells in the germline. Molecular Reproduction and Development, 42 : 379-387. 1995.

10) Kagami H, Tagami $T$, Matsubara $Y$, Harumi $T$, Hanada H, Maruyama K, Sakurai M, Kuwana T, Naito M. The developmental origin of primordial germ cells and the transmission of the donor-derived gametes in mixed-sex germline chimeras to the offspring in the chicken. Molecular Reproduction and 
Development, 48 : 501-510. 1997.

11) Kagami H, Hanada $H$. Current knowledge of sexual differentiation in domestic fowl. World's Poultry Science Journal, 53 : 111-123. 1997.

12) Meyer DB. The migration of primordial germ cells in the chick embryo. Developmental Biology, $10: 154$ 190. 1964.

13) Muniesa P, Dominguez L. A morphological study of primordial germ cells at pregastrular stages in the chick embryo. Cell Differentiation and Development, 31 : 105-117. 1990.

14) Naito $M$, Nirasawa $K$, Oishi $T$. Development in culture of the chick embryo from fertilized ovum to hatching. Journal of Experimental Zoology, $254: 322$ $-326.1990$.

15) Naito M, Tajima A, Yasuda $Y$, Kuwana T. Production of germline chimeric chickens, with high transmission rate of donor-derived gametes, produced by transfer of primordial germ cells. Molecular Reproduction and Development, 39 : 153-161. 1994.

16) Ono $T$, Murakami $T$, Mochii $M$, Agata $K$, Kino $K$, Otsuka K, Ohta M, Mizutani M, Yoshida M, Eguchi G. A complete culture system for avian transgenesis, supporting quail embryos from single-cell stage to hatching. Developmental Biology, 161 : 126-130. 1994.

17) Pain B, Clark ME, Shen M, Nakazawa H, Sakurai M, Samarut J, Etches RJ. Long-term in vitro culture and characterization of avian embryonic stem cells with multiple morphogenetic potentialities. Development, 122 : 2339-2348, 1996.

18) Pardanaud L, Buck C, Dieterlen-Liever F. Early germ cell segregation and distribution in the quail blastodisc. Cell Differentiation, 22 : 47-60. 1987.

19) Perry M. A complete culture system for the chick embryo. Nature, $331:$ 70-72. 1988.

20) Petitte JN, Clark ME, Liu G, Gibbins AM, Etches RJ. Production of somatic and germline chimeras in the chicken by transfer of early blastodermal cells. Development, 108 : 185-189, 1990.

21) Tagami $T$, Matsubara $Y$, Hanada $H$, Naito $M$. Differentiation of female chicken primordial germ cells into spermatozoa in male gonads. Development Growth and Differentiation, $39: 267-271.1997$.

22) Tagami $T$, Kagami H. Developmental origin of avian primordial germ cells and its unique differentiation in the gonads of mixed-sex chimeras. Molecular Reproduction and Development, $50: 370-376.1998$.

23) Tajima A, Naito M, Yasuda Y, Kuwana, T. Production of germline chimera by transfer of primordial germ cells in the domestic chicken (Gallus domesticus). Theriogenology, $40: 509-519.1993$.

24) Tajima A, Naito M, Yasuda $Y$, Kuwana T. Production of germ-line chimeras by transfer of cryopreserved gonadal primordial germ cells (gPGCs) in chicken. Journal of Experimental Zoology, 280 : 265267. 1998

25) Urven LE, Erickson CA, Abbott UK, McCarrey JR. Analysis of germline development in the chicken embryo using an anti mouse ES cell antibody. Development, 103 : 299-304. 1988.

26) Watanabe $M$, Naito $M$, Sasaki $E$, Sakurai $M$, Kuwana T, Oishi T. Liposome-mediated DNA transfer into chicken primordial germ cells in vivo. Molecular Reproduction and Development, 38 : 268-274. 1994. 